\begin{tabular}{cc|c}
\hline Tar. Bil. Der. & Tarm Bilimleri Dergisi & Journal of Agricultural Sciences \\
& $\begin{array}{c}\text { Dergi web sayfası: } \\
\text { www.agri.ankara.edu.tr/dergi }\end{array}$ & Journal homepage: \\
& www.agri.ankara.edu.tr/journal
\end{tabular}

\title{
Convective Drying Kinetics and Quality Parameters of European Cranberrybush
}

\author{
Onur TAŞKIN ${ }^{\mathrm{a}}$, Gökçen İZLi $\dot{I}^{\mathrm{b}}$, Nazmi İZLİ \\ a Bursa Uludag University, Faculty of Agriculture, Department of Biosystems Engineering, Bursa, TURKEY \\ ${ }^{\boldsymbol{b}}$ Bursa Technical University, Faculty of Natural Sciences, Architecture and Engineering, Department of Food Engineering, Bursa, \\ TURKEY
}

\section{ARTICLE INFO}

Research Article

DOI: 10.15832 ankutbd.456654

Corresponding Author: Nazmi İZLİ, E-mail: nazmiizli@gmail.com, Tel: +90 (224) 2941604

Received: 08 February 2017, Received in Revised Form: 16 May 2017, Accepted: 16 May 2017

\begin{abstract}
In this research, the effects of convective drying $\left(60,70,80\right.$ and $\left.90{ }^{\circ} \mathrm{C}\right)$ techniques on the drying kinetics, color, antioxidant capacity and total phenolic content of European cranberrybush were investigated in detail. To choose the best thin-layer drying models for the drying treatments, 10 mathematical models were compared for the experimental data. Depending on the evaluation by statistical tests, the Midilli et al model was determined to be the best suitable model to explain the drying behavior of European cranberrybush samples. All of the colorimetric parameters were influenced by drying temperatures. Antioxidant capacity and total phenolic content values of European cranberrybush samples displayed a significant reduction at low-temperature levels $\left(60\right.$ and $\left.70^{\circ} \mathrm{C}\right)$ with regard to those at high-temperature levels $\left(80\right.$ and $\left.90^{\circ} \mathrm{C}\right)$. In addition, the correlation analysis between antioxidant capacity and total phenolic content exhibited a high degree of correlation $\left(R^{2}=0.8656\right)$.
\end{abstract}

Keywords: European cranberrybush; Drying characteristics; Colorimetric parameters; Total phenolic content; Antioxidant capacity

(C) Ankara Üniversitesi Ziraat Fakültesi

\section{Introduction}

European cranberrybush (Viburnum opulus L.) species comes from the Caprifoliaceae plant family. Despite being grown mostly around the city of Kayseri, Turkey and called gilaburu, European cranberrybush is today common in eastern, western, northeastern, and central Europe (Yilmaztekin \& Sislioglu 2015) and known as European cranberrybush (Kayaçelik et al 2015), Guelder rose or Cramp bark (Velioğlu et al 2006). It contains a high amount of polyphenolics, including phenolic acids and anthocyanins, as well as organic acids such as ascorbic and L-malic acids (Kraujalytė et al 2013). The European cranberrybush is utilized as a traditional and folk medicine by European, Asian and Native American people. It is thought that fruits features have a preventive effect on cough, cramps, stomachache, uterine infections, menstrual cramps, blood pressure, infertility, asthma, nervousness, cold, fever and water retention problems (Sagdic et al 2014). Locally, European cranberrybush fruit is used in preparing jelly, jam, marmalade and sweetmeat too (Rop et al 2010) but it is not eaten directly due to its acidic taste (Kayaçelik et al 2015). 
Drying method is commonly used for the prolonged shelf-life, significant volume reduction, and product diversity, and these benefits could be extended even more, with enhancements in the quality of product and process applications. Hot air drying method has lots of benefits, for instance, decrease microbial contamination and provide a more uniform, the minimal adverse impact of weather conditions, shorter drying periods, and cheaper labor costs compared to traditional drying technique (Karabulut et al 2007). Various agricultural products have been dried by successfully applying hot air such as onion (Mota et al 2010), pear (Purkayastha et al 2013), apricot (Albanese et al 2013), cherry tomatoes (An et al 2013), mango (Murthy \& Manohar 2014) and jackfruit (Saxena $\&$ Dash 2015). However, very few numbers of researches have been conducted about the drying process of European cranberrybush. The aim of the study is to specify drying kinetics of the thin layer, to examine the differences with regard to color, total phenolic content (TPC), and antioxidant activity (AC) of the dried and fresh European cranberrybush samples.

\section{Material and Methods}

\subsection{Drying equipment and procedure}

Samples of fresh European cranberrybushes were gathered from the fields of Corekdere Village, Kayseri, Turkey. The fruits were kept to dry at $4 \pm 0.5{ }^{\circ} \mathrm{C}$ till to the drying experiments. In all experiments totally matured and healthy European cranberrybushes (average diameter of 10.52 \pm 0.09 $\mathrm{mm}$ ) were used. Their initial moisture content was determined to be 5.10 ( $\mathrm{g}$ water $\mathrm{g}$ dry matter $^{-1}$ ) on a dry basis (db) by forced-air convection oven (ED115 Binder, Tuttlingen, Germany) which was drying at the temperature of $105^{\circ} \mathrm{C}$ for the period of 24 hours (Hii et al 2012). Drying was continued until the final moisture content of the samples reached 0.1 ( $\mathrm{g}$ water $\mathrm{g}$ dry matter ${ }^{-1}$ ). The convective drying process was conducted in a laboratory convective oven (Whirlpool AMW 545, Italy). A rotating round plate of a glass material which has $400 \mathrm{~mm}$ diameter was used to put cranberrybush samples in a thin layer. For the drying procedure, the velocity of air was defined as $1.5 \mathrm{~m} \mathrm{~s}^{-1}$, and air temperatures were defined as $60,70,80$ and $90{ }^{\circ} \mathrm{C}$. A digital balance (Shimadzu UX-6200H, Tokyo, Japan) that has 0.01 $\mathrm{g}$ precision was placed under the oven to measure the mass change (Giri \& Prasad 2007). All of the experiments were carried out in triplicate.

\subsection{Mathematical modeling of the drying data}

The data about moisture content which was gathered by means of the drying experiment were converted to the moisture ratio $(M R)$ and fitted by using ten thin-layer drying models (Table 1). The moisture ratio was confirmed by making use of the Equation 1.

$M R=\frac{M_{t}-M_{e}}{M_{o}-M_{e}}$

Where; $M_{o}$, initial moisture content (g water $\mathrm{g}$ dry matter $\left.{ }^{-1}\right) ; M_{t}$, moisture content at a particular time ( $\mathrm{g}$ water $\mathrm{g}$ dry matter $^{-1}$ ); $M_{e}$, equilibrium moisture content ( $\mathrm{g}$ water $\mathrm{g}$ dry matter ${ }^{-1}$ ). $M R$ value was simplified to Equation 2. Since, $M_{e}$ values are relatively insignificant when they are compared to $M_{t}$ or $M_{o}$.

$M R=\frac{M_{t}}{M_{o}}$

\subsection{Color measurement}

Colors of the dried and fresh European cranberrybush samples were confirmed in the color scales of $L, a$ and $b$ by the using external surface of the samples with Hunterlab Color Analyzer (MSEZ-4500L, Reston, Virginia, USA). Color measurements were stated in a three-dimensional $L^{*}, a^{*}$, and $b^{*}$ color spaces, where $L^{*}$ stands for the darknesslightness of the sample, $a^{*}$ stands for the greenness (negative $(-)$ value) and the redness (positive (+) value), and $b^{*}$ stands for the blueness (negative (-) value) and the yellowness (positive (+) value). $L_{0}{ }^{*}, a_{0}{ }^{*}$ and $b_{0}{ }^{*}$ represent color parameters of the fresh samples. 
Table 1- Thin layer drying models used for mathematical modelling of the drying kinetics of European cranberrybush samples

\begin{tabular}{llll}
\hline No & Model name & Model & References \\
\hline 1 & Henderson and Pabis & $M R=a \exp (-k t)$ & Demiray \& Tulek (2014) \\
2 & Newton & $M R=\exp (-k t)$ & Saxena \& Dash (2015) \\
3 & Page & $M R=\exp \left(-k t^{n}\right)$ & Murthy \& Manohar (2014) \\
4 & Logarithmic & $M R=a \exp (-k t)+c$ & Mota et al (2010) \\
5 & Two term & $M R=a \exp \left(-k_{0} t\right)+b \exp \left(-k_{1} t\right)$ & Bhattacharya et al (2015) \\
6 & Two term exponential & $M R=a \exp (-k t)+(1-a) \exp (-k a t)$ & Evin (2011) \\
7 & Wang \& Singh & $M R=1+a t+b t^{2}$ & Arumuganathan et al (2009) \\
8 & Diffusion pproach & $M R=a \exp (-k t)+(1-a) \exp (-k b t)$ & Menges \& Ertekin (2006) \\
9 & Verma et al & $M R=a \exp (-k t)+(1-a) \exp (-g t)$ & Faal et al (2015) \\
10 & Midilli et al & $M R=a \exp \left(-k t^{n}\right)+b t$ & Midilli et al (2002) \\
\hline
\end{tabular}

After the calibration of the colorimeter against standard black and white surfaces, six replicate measurements were conducted for each sample. In order to explain the color changes, chroma $(C)$ and hue angle $(\alpha)$ total color difference $(\Delta E)$ values were figured out using the $L_{0}{ }^{*}, a^{*}, b^{*}, a_{0}{ }^{*}$ and $b_{0}{ }^{*}$ parameters which have been defined by Equations 3, 4 and 5 (Maskan 2001).

$$
\begin{aligned}
& C=\sqrt{\left(a^{2}+b^{2}\right)} \\
& \alpha=\tan ^{-1}\left(\frac{b}{a}\right) \\
& \Delta E=\sqrt{\left(L^{*}-L_{0} *\right)^{2}+\left(a^{*}-a_{0} *\right)^{2}+\left(b^{*}-b_{0} *\right)^{2}}
\end{aligned}
$$

\subsection{Preparation of sample extracts}

The extraction procedure was conducted by conforming to the method of Turkmen et al (2005). Homogenized $1 \mathrm{~g}$ of European cranberrybush samples with $4.5 \mathrm{~mL}$ of water:methanol (20:80 v:v) was shaken at $140 \mathrm{rpm}$ (Biosan OS-20, Latvia) for 120 minutes at room temperature. Following, the solutions were centrifuged for a duration of 15 minutes at 10,000 $g$ (Sigma $3 \mathrm{~K} 30, \mathrm{UK})$ and the supernatants were gathered up. The two extractions were conducted with pellet by using the same conditions. After the combination of obtained supernatants, they were passed through a PTFE membrane filter of $0.45 \mu \mathrm{m}$ in order to determine $\mathrm{AC}$ and TPC values of the samples. Extraction procedures were carried out in triplicate.

\subsection{Determining total phenolic contents}

The total phenolic content of the fruit was examined in line with the method of Igual et al (2012) with some changes on it, for instance, using gallic acid (GA) as the standard. European cranberrybush extracts $(0.25$ $\mathrm{mL}$ ) were blended with Folin-Ciocalteu reagent of $1.25 \mathrm{~mL}$ (Sigma-Aldrich, Germany) and distilled water of $15 \mathrm{~mL}$ on a vortex mixer (WiseMix VM-10, Daihan, South Korea). After this mixture was stored in the dark for 8 minutes, $3.75 \mathrm{~mL}$ of $7.5 \% \mathrm{Na}_{2} \mathrm{CO}_{3}$ was added to the mixture and then with distilled water, the volume was completed to $25 \mathrm{~mL}$. Lastly, the absorbance was gauged in a spectrophotometer (Optizen $3220 \mathrm{UV}$, Mecasys, Korea) at $765 \mathrm{~nm}$ and then compared with a GA calibration curve (with a concentration range of 5-50 $\mathrm{mg} \mathrm{L}^{-1}$ ). These results were stated as mg GA $100 \mathrm{~g}^{-1}$ on a dry weight. All of these measurements were conducted in triplicate.

\subsection{Determining antioxidant capacity}

The antioxidant capacity (AC) was assessed by the DPPH (2,2-diphenyl-1-picrylhydrazyl) free-radical scavenging activity of the European cranberrybush extracts in compliance with the method defined by Alothman et al (2009) sample extract $(0.1 \mathrm{~mL})$ 
which was appropriately diluted was put into $3.9 \mathrm{~mL}$ of $25 \mathrm{mM}$ DPPH methanolic solution. After mixing (WiseMix VM-10, Daihan, Korea) approximately about 15 to 30 seconds and kept dark to wait at room temperature for 30 minutes, absorbance values were gauged at $515 \mathrm{~nm}$ (Optizen $3220 \mathrm{UV}$, Mecasys, Korea). Methanol solutions of known trolox concentrations which were between 0.1 to $1.0 \mathrm{mM}$ were used in the calibration curve and the obtained outcomes were stated as $\mu$ mol trolox equivalents (TE) (Merck, Germany) per $1 \mathrm{~g}$ dry weight. All measurements were done in triplicate as well.

\subsection{Statistical analysis}

The study was carried out by using the randomized plots factorial design of experimental type. During the measuring process of the examined components, three replicates were used. To analyze these results, JMP (Version 7.0, SAS Institute Inc., Cary, NC, USA) and MATLAB (MathWorks Inc., Natick, MA) software packages were used. The significance of mean differences was tested and the LSD test (Least Significant Difference Test) resulted in 5\% of significance level. The model which has the lowest reduced chi-squared $\left(\chi^{2}\right)$ and RMSE (Root Mean Square Error) values, as well as the highest coefficient of determination, $\left(R^{2}\right)$ was concluded to be the optimal model that describes the drying characteristics of pineapples in a thin layer (Chayjan et al 2015). The explanations of these statistical values are on Equations 6 and 7 (Doymaz \& Ismail 2011).

$\chi^{2}=\frac{\sum_{i=1}^{N}\left(M R_{\text {exp }, i}-M R_{p r e, i}\right)^{2}}{N-z}$

$R M S E=\sqrt{\frac{\sum_{i=1}^{n}\left(M R_{p r e, i}-M R_{\mathrm{exp}, i}\right)}{N}}$

Where; $M R_{\text {exp }, i}$, experimental moisture ratio at the test number i; $M R_{p r e, i}$, estimated moisture ratio at the test number i; $N$, observation number; $z$, total count of constants used in the drying model.

\section{Results and Discussion}

\subsection{Drying kinetic of dried European cranberrybush}

The shifts in moisture content of the European cranberrybush samples which is represented as a drying duration function at various temperatures are showed in Figure 1. Drying duration of European cranberrybush samples which were dried at air temperatures of $60,70,80$ and $90{ }^{\circ} \mathrm{C}$ with a fixed drying air velocity of $1.5 \mathrm{~m} \mathrm{~s}^{-1}$ were lasted about 480, 310, 210 and 130 minutes, respectively. The outcomes of the experiment have shown that the average total drying duration for European cranberrybush at $90{ }^{\circ} \mathrm{C}$ was 250 minutes shorter than that of $60{ }^{\circ} \mathrm{C}$. In other words, the drying time dropped $52.08 \%$ when the temperature of air raised from 60 to $90{ }^{\circ} \mathrm{C}$. Considering these findings, it can be deduced that the increase in the drying temperature will boost the kinetic energy of water molecules and ultimately it triggers the water evaporation rate. That way, the drying duration reduces when the temperature increases. These obtained results are analogous with those asserted by Doymaz (2007) for sour cherry, Karabulut et al (2007) for apricot, Fang et al (2009) for jujube and Vega-Gálvez et al (2014) for cape gooseberry.

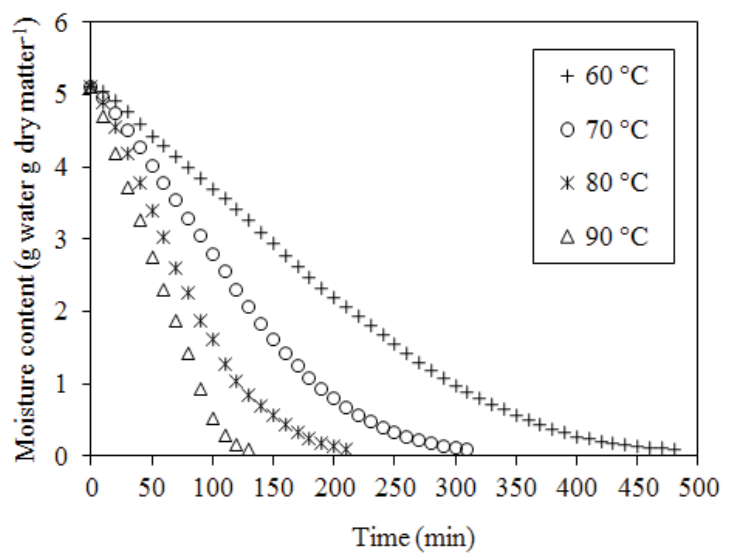

Figure 1- Drying curves of the European cranberrybush samples at different drying air temperatures 


\subsection{Suitability of drying curves}

The obtained values from the statistical analysis, containing the model constants and $R^{2}, R M S E$ and $\chi^{2}$ values, for all thin-layer drying models are in accordance with the data about moisture ratio are shown in Table 2. Separately, in all cases, the $R^{2}$, $R M S E$ and $\chi^{2}$ values for all of the models being used varied from 0.9252 to $0.9996,0.0068$ to 0.0939 and $0.2908 \times 10^{-4}$ to $85.1498 \times 10^{-4}$, respectively. With reference to these results, all the thin layer drying models discussed in this research sufficiently explained the drying kinetics of European cranberrybush. When the statistical values of these ten models are compared, the model of Midilli et al produced greater $R^{2}$ value and smaller RMSE and $\chi^{2}$ values. For all drying conditions, the $R^{2}, R M S E$ and $\chi^{2}$ values of the Midilli et al model, ranged between 0.9961 and $0.9996,0.0068$ and 0.0215 and $0.2908 \times 10^{-4}$ and $3.8142 \times 10^{-4}$, respectively. In compliance with the results above, the Midilli et al model was convincing in explaining the thin-layer drying curves of European cranberrybush samples. Figure 2 displays plots of experimental MR values and those estimated values which use the most appropriate models for drying duration at chosen drying conditions of European cranberrybush. It can be observed that for all of the drying conditions the estimated values obtained from the Midilli

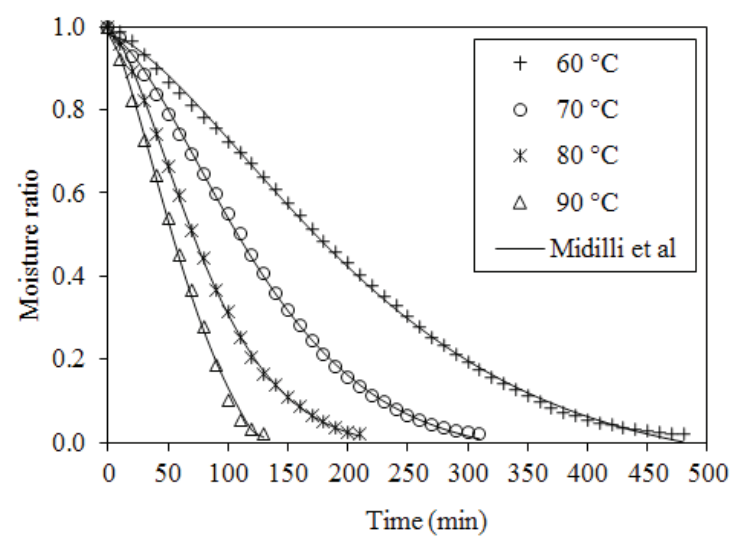

Figure 2- A comparison of the experimental and predicted moisture ratio for the Midilli et al model at different drying air temperatures et al model offered good conformity with the experimental data. Consequently, the model of Midilli et al was considered as a preferable model to explain the characteristic features of European cranberrybush for every temperature between 60 $80^{\circ} \mathrm{C}$. These findings are in good concordance with former studies. Other authors have also stated that Midilli et al is an adequate model to suit drying kinetics, including Gupta et al (2014) for aonla, Chayjan et al (2015) for hawthorn and Darici \& Sen (2015) for kiwi.

\subsection{Color analysis}

The color parameters of the dried European cranberrybush fruits were influenced by the different drying temperature as demonstrated at Table 3 . The $\mathrm{L}^{*}, \mathrm{a}^{*}$, and $\mathrm{b}^{*}$ chromatic parameters of fresh fruit were $24.37,42.99$, and 29.40, respectively. These values that belong to all dried samples decreased with regard to the values from the fresh European cranberrybush $(\mathrm{P}<0.05)$. Among the used four drying temperatures, the highest $a^{*}, b^{*}$ and $L^{*}$ values were acquired with the drying temperature at $60{ }^{\circ} \mathrm{C}$, while the greatest loss at $a^{*}, b^{*}$ and $L^{*}$ values was obtained with the drying temperature at $90{ }^{\circ} \mathrm{C}$. It is seen that a rise in drying temperature induced an outstanding brown products formation. In other respects, the $C$ and $\alpha$ values were affected by the increasing drying temperature in opposite ways. Among all of the drying treatments, drying at $60^{\circ} \mathrm{C}$ generated the highest $C$ value (38.03) and the lowest $\alpha$ value (28.04). Additionally, there was a decrease in $C\left(44 \%\right.$ at $\left.90{ }^{\circ} \mathrm{C}\right)$ and $\alpha$ values $\left(18 \%\right.$ at $\left.60{ }^{\circ} \mathrm{C}\right)$ of dried samples with regard to fresh fruit $(\mathrm{P}<0.05)$. This points that drying has resulted in discoloration of the original European cranberrybush color. Since, $\Delta E$ is a function of $L^{*}, a^{*}$ and $b^{*}$ values Equation 5, changes from 15.46 to 23.77 , which were predicted to be 60 and $90{ }^{\circ} \mathrm{C}$, respectively. As a result, the high $\Delta E$ values acquired at high drying temperature probably due to the impact of high temperatures on heat-sensitive components such as carbohydrates and proteins, amongst others (Vega-Gálvez et al 2009). Similar impacts of high drying temperatures on $\Delta E$ values have been stated for pulp and orange 


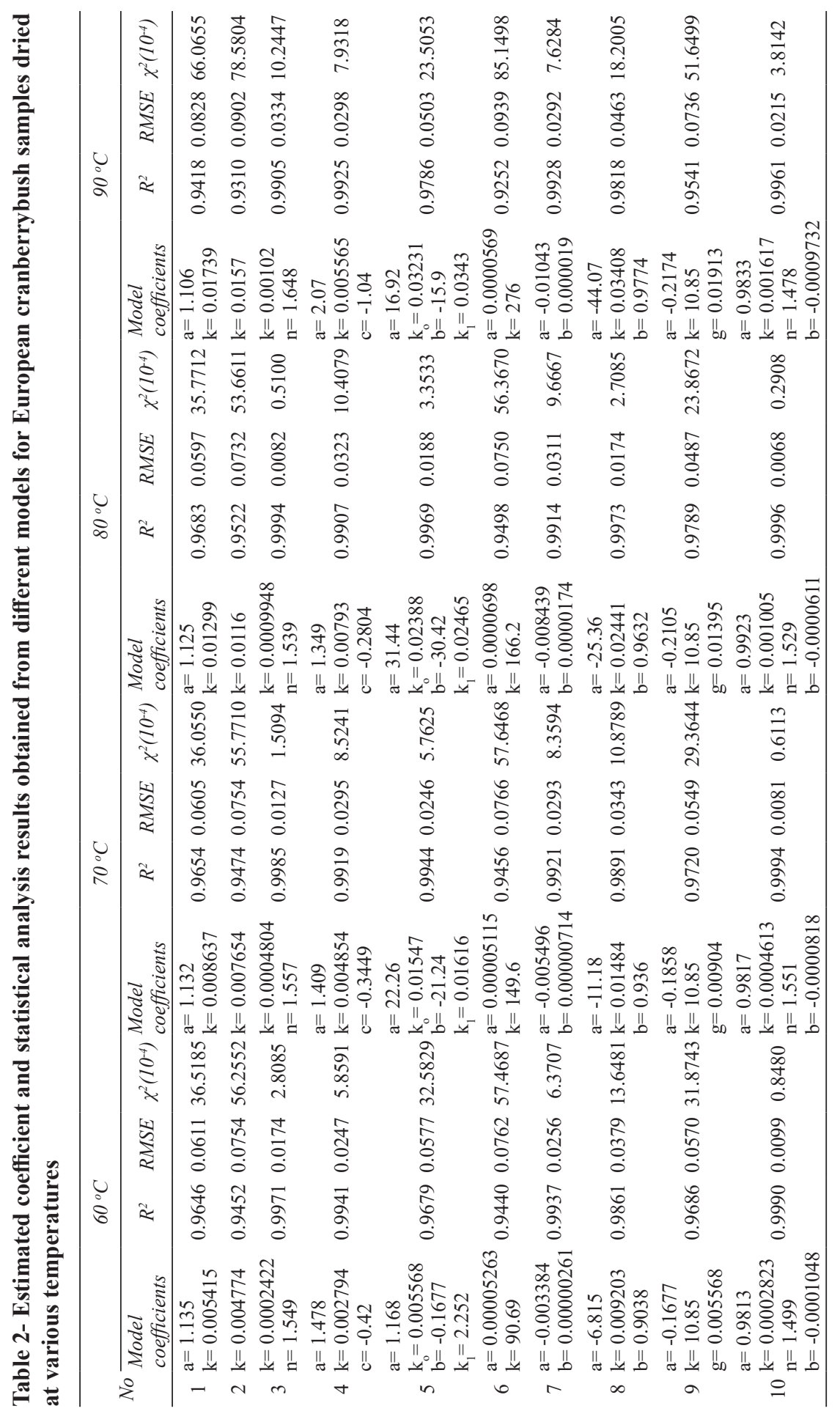


Table 3- Color values of fresh and dried European cranberrybush samples

\begin{tabular}{|c|c|c|c|c|c|c|}
\hline \multirow{2}{*}{$\begin{array}{l}\text { Drying } \\
\text { method }\end{array}$} & \multicolumn{6}{|c|}{ Color parameters } \\
\hline & $L^{*}$ & $a^{*}$ & $b^{*}$ & $C$ & $\alpha^{\circ}$ & $\Delta E$ \\
\hline Fresh & $24.37 \pm 1.41^{\mathrm{a}}$ & $42.99 \pm 1.48^{\mathrm{a}}$ & $29.40 \pm 1.15^{\mathrm{a}}$ & $52.09 \pm 1.65^{\mathrm{a}}$ & $34.38 \pm 0.99^{a}$ & - \\
\hline $60^{\circ} \mathrm{C}$ & $20.35 \pm 0.73^{b}$ & $33.57 \pm 1.10^{\mathrm{b}}$ & $17.86 \pm 0.66^{\mathrm{b}}$ & $38.03 \pm 1.13^{\mathrm{b}}$ & $28.04 \pm 0.91^{\mathrm{c}}$ & $15.46 \pm 0.93^{\mathrm{a}}$ \\
\hline $70^{\circ} \mathrm{C}$ & $19.57 \pm 0.38^{\mathrm{bc}}$ & $30.10 \pm 0.73^{c}$ & $17.60 \pm 0.45^{\mathrm{b}}$ & $34.87 \pm 0.60^{\mathrm{c}}$ & $30.34 \pm 1.02^{b}$ & $18.14 \pm 0.53^{b}$ \\
\hline $80^{\circ} \mathrm{C}$ & $19.05 \pm 1.00^{c}$ & $27.62 \pm 0.90^{\mathrm{d}}$ & $16.42 \pm 0.58^{\mathrm{c}}$ & $32.14 \pm 0.83^{\mathrm{d}}$ & $30.76 \pm 1.19^{b}$ & $20.84 \pm 0.90^{\mathrm{c}}$ \\
\hline $90^{\circ} \mathrm{C}$ & $18.82 \pm 0.46^{\mathrm{c}}$ & $24.12 \pm 0.65^{\mathrm{e}}$ & $16.08 \pm 0.95^{\mathrm{c}}$ & $29.00 \pm 0.75^{\mathrm{e}}$ & $33.69 \pm 1.71^{\mathrm{a}}$ & $23.77 \pm 0.71^{\mathrm{d}}$ \\
\hline
\end{tabular}

$L^{*}$, lightness; $a^{*}$, redness; $b^{*}$, yellowness; $C$, chroma; $\alpha^{\circ}$, hue angle; $\Delta E$, total color difference; ${ }^{\text {a-e }}$, values with different letters in same column differ significantly $(\mathrm{P}<0.05)$

peel by Garau et al (2007) and for sour cherries by Wojdyło et al (2014). European cranberrybush fruits are among the fruits which are most abundant sources of anthocyanin which is the source of the red color of the fruit.

Anthocyanins are easily converted to colorless or undesirable brown degradation compounds. The most apparent factor that can affect anthocyanin stability is a thermal treatment (Moldovan et al 2012). Considering this fact, the decline in $a^{*}$, $b^{*}$ and $L^{*}$ values as a consequence of drying treatments of European cranberrybush samples can be intensely associated with the degradation of anthocyanins and formation of brown pigments by non-enzymatic or Maillard reaction and enzymatic reaction, particularly at higher drying temperatures (Zanoni et al 1999).

\subsection{Total phenolic content}

The obtained results about the changes in TPC of European cranberrybush samples caused by the various drying temperatures have been demonstrated in Figure 3. The initial TPC value in

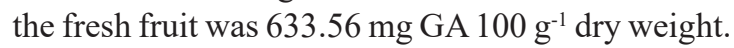
After drying treatments, the TPC value declined by $14-48 \%$. Due to drying treatments, the declines in the ingredient of total phenolic compounds were in conformance with former researches that phenolics compounds were heated labile and that continuous heat treatment may lead to irrevocable chemical modifications at phenolic compounds. It was stated that a decline in the TPC value in the course of drying also may be referred to the association of phenolics with other compounds (such as proteins) or to changes in chemical structures of the phenolic compounds that can not be obtained or confirmed by current methods on hand (Mrad et al 2012). Furthermore, from between the all dried samples, the TPC value demonstrated higher values at hightemperature levels $\left(80\right.$ and $\left.90{ }^{\circ} \mathrm{C}\right)$ with regard to low-temperature levels $\left(60\right.$ and $\left.70{ }^{\circ} \mathrm{C}\right)(\mathrm{P}<0.05)$. In addition, some researches have also stated that long drying periods linked to low drying temperature may incite reduction of TPC (Garau et al 2007; Lopez et al 2010). One issue that was remarkable was the decrease of TPC at the $90{ }^{\circ} \mathrm{C}$ drying condition with respect to $80{ }^{\circ} \mathrm{C}$ drying condition. That was possibly due to phenolic compounds from European cranberrybush samples have lower resistance to heat at $90{ }^{\circ} \mathrm{C}$.

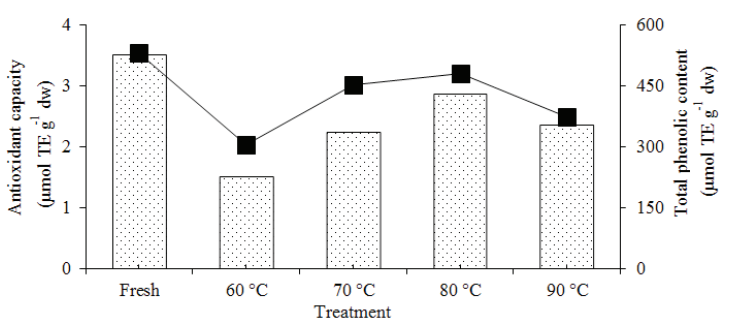

Figure 3- The effects of drying temperatures on the antioxidant capacity $(\because)$ ) and total phenolic content $(-$ ) of European cranberrybush samples

\subsection{Antioxidant capacity}

Figure 3 displays the AC values for the dried and fresh samples of European cranberrybush. It was monitored that all of the drying treatments ended in a decline of $\mathrm{AC}$ value, with respect to 
the fresh sample $(\mathrm{P}<0.05)$, in line with those ones reported for blueberry (Lopez et al 2010) and apple (Sultana et al 2012). This issue can be described by the thermal damage of antioxidant compounds during the long duration of drying treatments. Particularly, the lowest AC value was seen at 60 ${ }^{\circ} \mathrm{C}$ (4.54 $\mu$ mol trolox $\mathrm{g}^{-1}$ dry weight), whereas the highest $\mathrm{AC}$ value was attained by drying at $80{ }^{\circ} \mathrm{C}$ ( $8.48 \mu \mathrm{mol}$ trolox $\mathrm{g}^{-1}$ dry weight). Additionally, the production and accumulation of Maillard products which has changing the degree of $\mathrm{AC}$ values could also improve their antioxidant features at hightemperature levels (Que et al 2008). Furthermore, the regression analysis demonstrated that the TPC value had a positive correlation $\left(R^{2}=0.8656\right)$ with $\mathrm{AC}$ value of the European cranberrybush and this relation suggested that phenolic compounds may be the cause for the $\mathrm{AC}$ value observed in the European cranberrybush samples. Also, positive correlations between TPC and AC values have also been stated (Sultana et al 2012; Zhou et al 2016).

\section{Conclusions}

This study has examined the influences of convective drying method on drying characteristics, color, antioxidant capacity and total phenolic content of European cranberrybush fruits. The obtained results have indicated that superior average drying rates were attained with superior temperatures. Statistical results indicated that Midilli et al model was turned out to be the most convenient model which represents the drying curves of European cranberrybush. With respect to the color, it was likely to deduce that drying at $60{ }^{\circ} \mathrm{C}$ led to small changes in the color of European cranberrybush while drying at $90{ }^{\circ} \mathrm{C}$ led to more intense color changes. The rise of drying temperature augmented the $\Delta E$ values. Additionally, $C$ and $\alpha$ value were influenced by increasing drying temperature in opposite ways. TPC and AC values were higher at high-temperature levels (80 and 90 ${ }^{\circ} \mathrm{C}$ ) with regard to low-temperature levels (60 and $\left.70{ }^{\circ} \mathrm{C}\right)(\mathrm{P}<0.05)$. Additionally, a good correlation was detected between TPC and AC values $\left(R^{2}=\right.$ $0.8656)$. Finally, according to the these obtained results, in order to preserve the TPC and AC of dried samples, it can be monitored that the most suitable temperature for drying would be nearly 80 ${ }^{\circ} \mathrm{C}$, which asserts that phenolic compounds from European cranberrybush samples have a higher resilience against heat decline.

\begin{tabular}{|c|c|}
\hline \multicolumn{2}{|c|}{ Abbreviations and Symbols } \\
\hline$M_{0}$ & $\begin{array}{l}\text { Initial moisture content, } \mathrm{g} \text { water } \mathrm{g} \text { dry } \\
\text { matter }^{-1}\end{array}$ \\
\hline$M_{t}$ & $\begin{array}{l}\text { The moisture content at a particular } \\
\text { time, g water g dry matter-1 }\end{array}$ \\
\hline$M_{e}$ & $\begin{array}{l}\text { Equilibrium moisture content, } \mathrm{g} \text { water } \\
\mathrm{g} \text { dry matter }{ }^{-1}\end{array}$ \\
\hline$M R_{e x p, i}$ & $\begin{array}{l}\text { Experimental moisture ratio at the test } \\
\text { number I }\end{array}$ \\
\hline$M R_{p r e, i}$ & $\begin{array}{l}\text { Estimated moisture ratio at the test } \\
\text { number } \mathrm{i}\end{array}$ \\
\hline$N$ & Observation number \\
\hline$z$ & Total count of constant \\
\hline RMSE & Root mean square error \\
\hline$R^{2}$ & Coefficient of determination \\
\hline & Reduced chi-square \\
\hline$a, b, c, g, n, k_{0}, k_{1}$ & Model constants \\
\hline
\end{tabular}

\section{References}

Albanese D, Cinquanta L, Cuccurullo G \& Di Matteo M (2013). Effects of microwave and hot air drying methods on color, $\beta$-carotene and radical scavenging activity of apricots. International Journal of Food Science and Technology 48(6): 1327-1333

Alothman M, Bhat R \& Karim A A (2009). Antioxidant capacity and phenolic content of selected tropical fruits from Malaysia, extracted with different solvents. Food Chemistry 115(3): 785-788

An K, Li H, Zhao D, Ding S, Tao H \& Wang Z (2013). Effect of osmotic dehydration with pulsed vacuum on hot-air drying kinetics and quality attributes of cherry tomatoes. Drying Technology 31(6): 698-706

Arumuganathan T, Manikantan M R, Rai R D, Anandakumar S \& Khare V (2009). Mathematical modelling of drying kinetics of milky mushroom in a fluidized bed dryer. International Agrophysics 23(1): $1-7$

Bhattacharya M, Srivastav P P \& Mishra H N (2015). Thin-layer modeling of convective and microwaveconvective drying of oyster mushroom (Pleurotus ostreatus). Journal of Food Science and Technology 52(4): 2013-2022 
Chayjan R A, Kaveh M \& Khayati S (2015). Modeling drying characteristics of Hawthorn fruit under microwave-convective conditions. Journal of Food Processing and Preservation 39(3): 239-253

Darici S \& Sen S (2015). Experimental investigation of convective drying kinetics of kiwi under different conditions. Heat Mass Transfer 51(8): 1167-1176

Demiray E \& Tulek Y (2014). Drying characteristics of garlic (Allium sativum L.) slices in a convective hot air dryer. Heat Mass Transfer 50(6): 779-786

Doymaz I (2007). Influence of pretreatment solution on the drying of sour cherry. Journal of Food Engineering 78(2): 591-596

Doymaz I \& Ismail O (2011). Drying characteristics of sweet cherry. Food and Bioproducts Processing 89(1): 31-38

Evin D (2011). Microwave drying and moisture diffusivity of white mulberry: Experimental and mathematical modeling. Journal of Mechanical Science and Technology 25(10): 2711-2718

Faal S, Tavakoli T \& Ghobadian B (2015). Mathematical modelling of thin layer hot air drying of apricot with combined heat and power dryer. Journal of Food Science and Technology 52(5): 2950-2957

Fang S, Wang Z \& Hu X (2009). Hot air drying of whole fruit Chinese jujube (Zizyphus jujube Miller): Thinlayer mathematical modelling. International Journal of Food Science and Technology 44(9): 1818-1824

Garau M C, Simal S, Rossello C \& Femenia A (2007). Effect of air-drying temperature on physico-chemical properties of dietary fibre and antioxidant capacity of orange (Citrus aurantium v. Canoneta) by-products. Food Chemistry 104(3): 1014-1024

Giri S K \& Prasad S (2007). Drying kinetics and rehydration characteristics of microwave-vacuum and convective hot-air dried mushrooms. Journal of Food Engineering 78(2): 512-521

Gupta R K, Sharma A, Kumar P, Vishwakarma R K \& Patil R T (2014). Effect of blanching on thin layer drying kinetics of aonla (Emblica officinalis) shreds. Journal of Food Science and Technology 51(7): 12941301

Hii C L, Law C L \& Suzannah S (2012) Drying kinetics of the individual layer of cocoa beans during heat pump drying. Journal of Food Engineering 108(2): 276-282

Igual M, García-Martínez E, Martín-Esparza M E \& Martínez-Navarrete N (2012). Effect of processing on the drying kinetics and the functional value of dried apricot. Food Research International 47: 284-290

Karabulut I, Topcu A, Duran A, Turan S \& Ozturk B (2007). Effect of hot air drying and sun drying on color values and $\beta$-carotene content of apricot (Prunus armenica L.). LWT-Food Science and Technology 40(5): 753-758

Kayaçelik A A, Küçük M, İskefiyeli Z, Smet S D, Miserez B \& Sandra P (2015). Antioxidant components of Viburnum opulus L. determined by on-line HPLCUV-ABTS radical scavenging and LC-UV-ESI-MS methods. Food Chemistry 175: 106-114

Kraujalytė V, Venskutonis P R, Pukalskas A, Česonienè L \& Daubaras R (2013). Antioxidant properties and polyphenolic compositions of fruits from different European cranberrybush (Viburnum opulus L.) genotypes. Food Chemistry 141(4): 3695-3702

Lopez J, Vergara J, Gonzalez E, Scala K D, Uribe E, Vega-Galvez A \& Miranda M (2010). Effect of air temperature on drying kinetics, vitamin $\mathrm{C}$, antioxidant activity, total phenolic content, non-enzymatic browning and firmness of blueberries variety O'Neil. Food and Bioprocess Technology 3: 772-777

Maskan M (2001). Drying, shrinkage and rehydration characteristics of kiwifruits during hot air and microwave drying. Journal of Food Engineering 48: 177-182

Menges H O \& Ertekin C (2006). Thin layer drying model for treated and untreated Stanley plums. Energy Conversion and Management 47: 2337-2348

Midilli A, Kucuk H \& Yapar Z (2002). A new model for single-layer drying. Drying Technology 20(7): 15031513

Mrad N D, Boudhrioua N, Kechaou N, Courtois F \& Bonazzi C (2012). Influence of air drying temperature on kinetics, physicochemical properties, total phenolic content and ascorbic acid of pears. Food and Bioproducts Processing 90(3): 433-441

Moldovan B, David L, Chişbora C \& Cimpoiu C (2012). Degradation kinetics of anthocyanins from European cranberrybush (Viburnum opulus L.) fruit extracts. Effects of temperature, $\mathrm{pH}$ and storage solvent. Molecules 17(10): 11655-11666

Mota C L, Luciano C, Dias A, Barroca M J \& Guiné R P F (2010). Convective drying of onion: Kinetics and nutritional evaluation. Food and Bioproducts Processing 88(2): 115-123 
Murthy T P K \& Manohar B (2014). Hot air drying characteristics of mango ginger: Prediction of drying kinetics by mathematical modelling and artificial neural network. Journal of Food Science and Technology 51(12): 3712-3721

Purkayastha M D, Nath A, Deka B C \& Mahanta C L (2013). Thin layer drying of tomato slices. Journal of Food Science and Technology 50: 642-653

Que F, Mao L, Fang X \& Wu T (2008). Comparison of hot air-drying and freeze-drying on the physicochemical properties and antioxidant activities of pumpkin (Cucurbita moschata Duch.) flours. International Journal of Food Science and Technology 43(7): 11951201

Rop O, Reznicek V, Valsikova M, Jurikova T, Mlcek J \& Kramarova D (2010). Antioxidant properties of European cranberrybush fruit (Viburnum opulus var. edule). Molecules 15: 4467-4477

Sagdic O, Ozturk I, Yapar N \& Yetim H (2014). Diversity and probiotic potentials of lactic acid bacteria isolated from gilaburu, a traditional Turkish fermented European cranberrybush (Viburnum opulus L.) fruit drink. Food Research International 64: 537-545

Saxena J \& Dash K K (2015). Drying kinetics and moisture diffusivity study of ripe Jackfruit. International Food Research Journal 22(1): 414-420

Sultana B, Anwar F, Ashraf M \& Saari N (2012). Effect of drying techniques on the total phenolic contents and antioxidant activity of selected fruits. Journal of Medicinal Plants Research 6: 161-167

Turkmen N, Sari F \& Velioglu S (2005). The effect of cooking methods on total phenolics and antioxidant activity of selected green vegetables. Food Chemistry 93: 713-718
Vega-Gálvez A, Scala K D, Rodríguez K, LemusMondaca R, Miranda M, López J \& Perez-Won M (2009). Effect of air-drying temperature on physicochemical properties, antioxidant capacity, colour and total phenolic content of red pepper (Capsicum annuum, L. var. Hungarian). Food Chemistry 117(4): 647-653

Vega-Gálvez A, Díaz L P, Mondaca R L, Miranda M \& Torres M J (2014). Mathematical modeling of thin layer drying kinetics of cape gooseberry (Physalis peruviana L.). Journal of Food Processing and Preservation 38(2): 728-736

Velioğlu Y S, Ekici L \& Poyrazoğlu E S (2006). Phenolic composition of European cranberrybush (Viburnum opulus L.) berries and astringency removal of its commercial juice. International Journal of Food Science and Technology 41: 1011-1015

Wojdyło A, Figiel A, Lech K, Nowicka P \& Oszmiański J (2014). Effect of convective and vacuum-microwave drying on the bioactive compounds, color, and antioxidant capacity of sour cherries. Food and Bioprocess Technology 7(3): 829-841

Yilmaztekin M \& Sislioglu K (2015). Changes in volatile compounds and some physicochemical properties of European cranberrybush (Viburnum opulus L.) during ripening through traditional fermentation. Journal of Food Science 80(4): 687-694

Zanoni B, Peri C, Nani R \& Lavelli V (1999). Oxidative heat damage of tomato halves as affected by drying. Food Research International 31(5): 395-401

Zhou L, Cao Z, Bi J, Yi J, Chen Q, Wu X \& Zhou M (2016). Degradation kinetics of total phenolic compounds, capsaicinoids and antioxidant activity in red pepper during hot air and infrared drying process. International Journal of Food Science and Technology 51(4): 842-853 